\title{
Cell proliferation and tissue remodeling are major determinants of cancer metabolism and the response to drugs targeting metabolism
}

\author{
Elke Markert ${ }^{1}$, Philip Tedeschi ${ }^{1}$, Sonia Dolphi ${ }^{1}$, Kim Hirshfield ${ }^{1}$, Joseph Bertino ${ }^{1}$, Zoltan Oltvai ${ }^{2}$, Alexei Vazquez ${ }^{1 *}$ \\ From Metabolism, Diet and Disease 2014: Cancer and metabolism \\ Washington DC, USA. 28-30 May 2014
}

\section{Background}

Alterations in cell proliferation and tissue remodeling are major hallmarks of cancer. Given that these two physiological processes require a significant investment of metabolic resources, we hypothesize that the metabolism of cancer cells is, in a first approximation, determined by the magnitude of cell proliferation and tissue remodeling.

\section{Materials and methods}

To address this question in further detail we have analyzed in vitro data characterizing cancer cell lines and gene expression profiles of human cancers.

\section{Results}

We show that the metabolism of cancer cells is strongly correlated with cell proliferation and tissue remodeling. Based on in vitro data, cancer cell lines align from an extreme of highly proliferating cells of relatively small size to another extreme of slowly proliferating cells with large size and mesenchymal properties [1]. Similarly, in human cancers we detect a strong negative correlation between gene signatures associated with cell proliferation and tissue remodeling [2]. The stratification of human cancers based on the cell-proliferation/ tissue-remodeling signatures results in divergence in the survival plots as significant as those obtained using current site-specific classifications. Furthermore, in vitro data suggest that these different subtypes have a differential sensitivity to diverse drug classes targeting metabolism [1].

\section{Conclusions}

We conclude that human cancers can be subject to a universal cell-proliferation/tissue-remodeling classification independent of their site of origin that can guide personalized treatment targeting cancer metabolism.

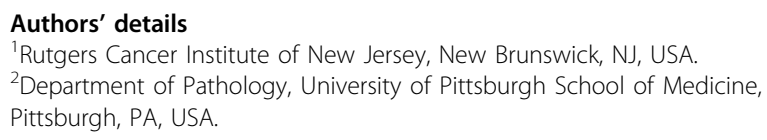

${ }^{1}$ Rutgers Cancer Institute of New Jersey, New Brunswick, NJ, USA. ${ }^{2}$ Department of Pathology, University of Pittsburgh School of Medicine, Pittsburgh, PA, USA.

\section{Published: 28 May 2014}

References

1. Dolfi SC, Chan LL, Qiu J, Tedeschi PM, Bertino JR, Hirshfield KM, Oltvai ZN, Vazquez A: The metabolic demands of cancer cells are coupled to their size and protein synthesis rates. Cancer Metab 2013, 1:20.

2. Markert EK, Levine AJ, Vazquez A: Proliferation and tissue remodeling in cancer: the hallmarks revisited. Cell Death Dis 2012, 3:e397.

doi:10.1186/2049-3002-2-S1-P80

Cite this article as: Markert et al:: Cell proliferation and tissue remodeling are major determinants of cancer metabolism and the response to drugs targeting metabolism. Cancer \& Metabolism 2014 2(Suppl 1):P80.

Submit your next manuscript to BioMed Central and take full advantage of:

- Convenient online submission

- Thorough peer review

- No space constraints or color figure charges

- Immediate publication on acceptance

- Inclusion in PubMed, CAS, Scopus and Google Scholar

- Research which is freely available for redistribution 